\begin{tabular}{|c|c|c|c|}
\hline Article Info & RESEARCH ARTICLE & ARAŞTIRMA MAKALESİ & \\
\hline Title of Article & \multicolumn{2}{|c|}{$\begin{array}{l}\text { Contribution of Ordu Metropolitan } \\
\text { Municipality Twitter Platform to the } \\
\text { Corporate Image of the Municipality }\end{array}$} & \\
\hline $\begin{array}{l}\text { Corresponding } \\
\text { Author }\end{array}$ & \multicolumn{2}{|c|}{$\begin{array}{l}\text { Prof.Dr. Cavit YAVUZ } \\
\text { Ordu Üniversitesi Turizm Fakültesi Öğr.Üyesi, yavuzcavit@hotmail.com }\end{array}$} & \\
\hline $\begin{array}{l}\text { Received Date } \\
\text { Accepted Date }\end{array}$ & \multicolumn{2}{|l|}{$\begin{array}{l}15.08 .2020 \\
31.12 .2020\end{array}$} & \\
\hline DOI Number & \multicolumn{2}{|l|}{ https://doi.org/10.35674/kent.780955 } & \\
\hline Author / Authors & $\begin{array}{l}\text { Prof.Dr. Cavit YAVUZ } \\
\text { Hasan Basri ZAVALSIZ }\end{array}$ & $\begin{array}{l}\text { ORCID: 0000-0001-9279-1740 } \\
\text { ORCID: 0000-0003-1242-6933 }\end{array}$ & \\
\hline How to Cite & \multicolumn{2}{|c|}{$\begin{array}{l}\text { Yavuz, C. ; Zavalsız, H. B., (2020). Ordu Büyükșehir Belediyesi Twitter Platformunun } \\
\text { Belediyenin Kurumsal İmajına Katkısı, Kent Akademisi, Volume, 14, Issue 1, Pages, } \\
\text { 186-198 }\end{array}$} & $\begin{array}{l}\text { Kent Akademisi } \\
\text { Urban Academy }\end{array}$ \\
\hline
\end{tabular}

\title{
Ordu Büyükşehir Belediyesi Twitter Platformunun Belediyenin Kurumsal İmajına Katkısı
}

\begin{abstract}
:
The rapid development of technology brings along some innovations in the internet field. The internet world, which is experiencing an innovative change day by day, has become an important communication element of institutions and organizations as well as individuals. Institutions and organizations that want to reach their activities to target audiences in the internet environment, give importance to image studies in their bodies and make efforts for this. In this sense, institutions and organizations try to preserve their corporate image in the long term through image management. Municipalities, which are a branch of local governments, are also in an effort to improve their corporate image studies. Today, municipalities deliver their work to their target audiences on social media platforms as well as traditional media tools. In our study, the posts made by Ordu Metropolitan Municipality between 01.09.2019 30.09.2019 on Twitter, which is an important social media platform of today, were tried to be analyzed using the content analysis method. As a result of the study; It is understood that the relevant platform is actively used by the fact that the posts made on the Ordu Metropolitan Municipality Twitter platform between the aforementioned dates were included in both the national press and local media organs. Shares were handled in the category of announcement, news, service, celebration, promotion and visit and it has been observed that most of the shares were made with the aim of informing the target audience.However, while some of the posts contribute to the institutional image of the municipality, it is also thought that some of them damage the institutional image.
\end{abstract}

KEYWORDS: Social Media, Twitter, Corporate İmage, Local Governments, Municipality

\footnotetext{
${ }^{1}$ Prof.Dr. Ordu Üniversitesi, Turizm Fakültesi, Turizm Işletmeciliği Bölümü 0000-0001-9279-1740

2 Yüksek Lisans Öğrencisi, bazri52@gmail.com 0000-0003-1242-6933
} 


\section{ÖZ:}

Teknolojin hızla gelişmesi internet alanında da bir takım yenilikleri beraberinde getirmektedir. Her geçen gün inovasyonel bir değişim yaşayan internet dünyası, sürekli gelişerek bireylerin olduğu kadar kurum ve kuruluşların da önemli bir iletişim unsuru haline gelmiştir. Faaliyetlerini internet ortamında hedef kitlelerine ulaştırmak isteyen kurum ve kuruluşlar, bünyelerinde imaj çalışmalarına önem vererek buna yönelik çabalar içerisinde olmaktadırlar. Bu manada kurum ve kuruluşlar oluşturdukları kurumsal imajlarını, imaj yönetimi marifetiyle uzun vadede korumaya çalışmaktadırlar. Yerel yönetimlerin bir kolu olan belediyeler de oluşturmuş olduğu kurumsal imaj çalışmalarını geliştirme çabası içindedir. Günümüzde belediyeler yapmış oldukları çalışmaları geleneksel medya araçlarının yanı sıra sosyal medya platformlarında da hedef kitlelerine ulaştırmaktadırlar. Çalışmamızda, Ordu Büyükşehir Belediyesi’nin 01.09.2019 - 30.09.2019 tarihleri arasında günümüzün önemli bir sosyal medya platformu olan Twitter ortamında yapmış olduğu paylaşımlar içerik analizi yöntemi kullanılarak incelenmeye çalışılmıştır. Çalışmanın sonucunda; Ordu Büyükşehir Belediyesi Twitter platformu üzerinden bahse konu tarihler arasında yapmış olduğu paylaşımların hem ulusal basında hem de yerel medya organlarında yer almasından, ilgili platformun aktif bir biçimde kullandığı anlaşılmaktadır. Yapılan paylaşımlar; duyuru, haber, hizmet, kutlama, tanıtım ve ziyaret kategorisinde ele alınmış olup; büyük bir kısmında hedef kitlenin bilgilendirilmesine yönelik paylaşımlar yapıldığı görülmüştür. Ancak yapılan paylaşımlardan bazıları belediyenin kurumsal imajına katkı sağlarken bazı paylaşımlarında ise kurumsal imaja zarar verdiği düşünülmektedir.

ANAHTAR KELIMELER: Sosyal Medya, Twitter, Kurumsal İmaj, Yerel Yönetimler, Belediye

\section{“Ordu Büyükşehir Belediyesi Twitter Platformunun Belediyenin Kurumsal İmajina Katkısı"}

\section{GíRiș:}

İletişim insanlığın var olduğu günden itibaren varlığını koruyarak insanlı̆̆ın her an ihtiyaç duyduğu bir kavram olarak hayatımızdaki yerini almıştır (Çavuş, 2011, s.7). Aynı zamanda iletişimin; bireylerin kendilerini ifade edebilmesi, kurumların da hedef kitlelerine yönelik daha anlaşılır olabilmesi için ihtiyaç duyulan bir araç olduğu bilinmektedir. Çağımızda bilişim teknolojisinde yaşanan olumlu gelişmeler bireylerin günlük hayatlarını değiştirirken kurum ve kuruluşların vatandaşla arasındaki iletişimini de etkilemiştir (Chun vd., 2010, s. 1).

Kurum ve kuruluşların birbirleriyle kurduğu iletişim, elektronik cihazların gelişmesiyle daha çeşitli hale gelmiştir. Zamanla çeşitlilik kazanan iletişim araçlarının önemi hızla artarken iletişim kavramının doğru bir düzlem üzerinde yönetilmesi için bir takım çalışmalar geliştirilmiştir. Yeni medya araçlarının ortaya çıkmasını ve her geçen gün gelişmesini sağlayan internet, bireylerin yanı sıra markalara, özel ve kamu kuruluşlarına çift yönlü bir iletişim avantajı sunmaktadır (Öztel, 2018, s. 6).

Yaşantımızı kolaylaştırmak için kullandığımız internet platformları, sunmuş olduğu kolaylıklar bakımından geleneksel medya mecralarından daha fazla tercih edilir duruma gelmiştir. Çünkü geleneksel medya araçları; hedef kitlesine tek taraflı bir şekilde mesaj göndermekte ve herhangi bir yanıt alamamaktadır (Tokatlı, 2015, s. 33). Tek yönlü iletişim aracı olarak nitelendirebileceğimiz gazete, dergi ve televizyon gibi iletişim araçlarının, gelişen teknolojiye karşı nispeten yetersiz olduğu düşünülmektedir. İnternet ortamında iki yönlü ve karşılıklı iletişimin kurulması, geleneksel medyaya karşı bir avantaj sağlamaktadır.

Sosyal medya yakın tarihte insanların, kurum ve kuruluşların hayatına girmiş ve bu alanda üretim ve tüketimin aynı anda yapıldığı bir ortam haline gelmiş olup; kültürel, siyasal, ekonomik ve sosyal disiplinlerde bireylerin erişim sağlayarak günlük hayatın seyrini değiştirebilen bir dinamik haline dönüşmüştür (Yavuz ve Duvan, 2018, s. 1335). Bireylerin sosyal medya platformlarını yoğun bir biçimde kullanması, özel ve resmi kurumlar gibi yerel yönetim organlarını da sosyal medyayı kullanmaya teşvik etmektedir. Çift yönlü iletişim imkânı sunan sosyal medya mecraları, anında geribildirim olanăg s sağlamasından dolayı tercih edilmektedir. Bu sebeple sosyal medya, belediyelerin hedef kitlesiyle yani vatandaşlarla doğrudan iletişim kurabildiği bir platform haline gelmiştir.

Belediyeler hedef kitleleriyle etkileşime geçerek belediye sınırları içerisinde yaşayan halkın ihtiyaçlarının karşılanması, daha yaşanabilir ortam ve imkanların sunulabilmesi noktasında bir çok faaliyet gerçekleştirmektedir. Bu faaliyetlerin hedef kitle açısından algılanış biçimi kurumsal imaj kavramını ortaya çıkarmakta ve belediyeyi kurumsal 
imaj oluşturmaya yönelik çalışmalara yönlendirmektedir. Aynı zamanda belediyenin; kaliteye, saygınlığa ve güvenilir bir yapıya sahip olması kurumsal imajı olumlu yönde etkilemektedir (Canöz, 2015, s. 49).

Kamuya hizmet eden kuruluşların rakiplerinden sıyrılarak hedef kitleye faaliyetlerini gösterme arzusu hızla artmaktadır. Bu durum aynı zamanda özel ve resmi kurumlar gibi sivil toplum örgütlerini de kapsamaktadır. Rekabetin hızla büyüdüğü bu günlerde kurumsal imajın belediyeler açısından oldukça önemli bir konu olduğu daha net anlaşılmaktadır. Başarılı bir kurumsal imaj yönetimi, kurumun yapmış olduğu her türlü faaliyetin içinde yer almaktadır. Bu durum ise kurumların bir sonraki faaliyetlerini desteklemektedir (Doğan, 2006, s. 80). Belediyelerin hedef kitlelerine yönelik yapmış olduklaları çalışmalar, hedef kitlenin algısında oluşan bir fotoğraf olarakda ifade edebileceğimiz kurumsal imajdır ki; bu durum hedef kitle ile kurulan ilişkide önemli bir role sahiptir.

\section{Alanyazın Taraması}

İnternet ve sosyal medya teknolojik gelişmeleri de içine alarak sosyoloji ve antropoloji gibi birçok bilim dalından faydalanmaktadır. Alanyazında sosyal medya ve kurumsal imajla ilgili çeşitli akademik çalışmalara rastlanmaktadır.

Demirkol'un (2017), "Belediyelerde Kurumsal İmaj Algısı Kırıkkale Belediyesi’nin Dış Hedef Kitleler Gözündeki İmajı” başlığı ile yaptığı çalışmada; Kırıkkale Belediyesi çalışanlarıyla görüşme tekniği yoluyla belediye hakkında genel bilgiler elde etmiş, ayrıca Kırıkkale'de yaşayan 18 yaş üzerindeki kişilerle anket çalışması yaparak, Kırıkkale Belediyesinin halk nezdindeki imajı değerlendirilmiş ve hedef kitle üzerinde oluşturduğu imaj etkisi araştırılmıştır. Çalışmanın sonucunda; Kırıkkale Belediyesi'nin hedef kitle gözündeki imajı, belediyenin imajını oluşturan faktörler ve önemlilik seviyesi ve bu faktörlerin meslek, yaş, cinsiyet, medeni durum, ikamet süresi, eğitim gibi bazı değişkenler arasındaki ilişkisi belirlenmeye çalışılmıştır.

Duvan'nın (2019), Karadeniz Bölgesinde bulunan 32 belediyenin kurumsal iletişimlerinde sosyal medya kullanımlarını ele aldığı "Karadeniz Bölgesindeki Belediyelerin Kurumsal İletişsiminde Sosyal Medya" adlı çalışmasında, belediyelerin kurumsal imaj ve kurumsal iletişimlerinin maksimum düzeye çıkartılmasında sosyal medya platformlarının kullanılmasının belediyelere önemli katkılar sağladığı ortaya çıkmıştır.

Kaygısız ve Sarı'nın (2015) yapmış olduğu “Belediyelerin Sosyal Medya Kullanımı Burdur Belediyesi ve Burdur İlçe Belediyeleri Üzerine Bir Araştırma" başlıklı çalışmada içerik analizi yöntemini kullanarak sosyal medya platformlarını daha etkin ve faydalı şekilde nasıl kullanılacağına ilişkin öneriler sunmaktadır. Çalışma sonucunda ilgili belediyeler; sosyal medya platformları aracılığı ile belediyeye ulaşan hedef kitleye ivedi ve kesin çözümler üreterek geri bildirim yapılması, sosyal medya platformlarının alanında uzman kişiler tarafından yönetilmesi ve sosyal medya platformlarında paylaşımların bir standardizasyon çerçevesinde yapılması gibi öneriler sunulmuştur.

Pirci Aydın'ın (2018), "Belediyelerde Halkla İlişkiler Aracı Olarak Sosyal Medya Kullanımı: Büyükşehir Belediyelerinin Twitter Hesapları Üzerine Bir İnceleme" başlığı ile yapmış olduğu çalışmada ise 30 Büyükşehir Belediyesinden 23 tanesinin Twitter hesaplarından belirli tarihler arasında yapmış oldukları paylaşımların içerik analizi yöntemiyle incelediği görülmektedir. Çalışmada; belediyelerin Twitter platformlarının kullanım davranışları incelenerek elde edilen sonuçlar doğrultusunda bahse konu platformun en etkin şekilde nasıl kullanılacağına dair öneriler sunulmuştur. Hedef kitleye en yakın kurum olarak algılanan belediyeler başta olmak üzere, kamu kurum ve kuruluşlarının her geçen gün gelişen web teknolojilerinin etkin ve aktif olarak kullanılması noktasında isteksiz oldukları çalışmanın sonuçlarından birisi olarak karşımıza çıkmaktadır.

Sayılganoğlu (2018) "Kurumsal İletişim Bağlamında Belediyelerde Kurumsal Twitter Hesabı Kullanımı" adlı çalışmasında Esenyurt Belediyesi, Küçükçekmece Belediyesi ve Bağcılar Belediyesi kurumsal Twitter platformları üzerinde 01.02.2018 - 28.02.2018 tarihleri arasında içerik analizi yöntemiyle araştırma yaparak elde edilen sonuçlara karşı çözüm önerileri sunmuştur. İlgili belediyelere ait Twitter platformlarında sorunları ileten, bilgi talep eden bir iletişim anlayışı öne çıkmakla birlikte, platformlara ait üye sayıları dikkate alındığında mevcut iletişimin sınırlı seviyede olduğu görülmüştür. Bununla birlikte ilgili belediyelere ait kurumsal Twitter hesaplarının bilgi aktarma ve bilgiyi yayma gibi faaliyetleri gösteren ve direkt olarak katılımı özendirmeyen bir biçimde kullanıldığı saptanmıştır.

Alanyazın incelendiğinde özel sektör kuruluşlarının yanı sıra kamu kurum ve kuruluşlarının da kurumsal imaj ve kurumsal iletişimlerinde sosyal medya platformlarını kullandığını görmekteyiz. Yaptı̆̆ımız çalışma sonucunda Ordu Büyükşehir Belediyesi Twitter platformunu çalışmaya esas tarihler arasında aktif bir biçimde kullandığı ve hedef kitlesiyle etkileşime geçme noktasında istekli olduğu anlaşılmıştır. Ordu Büyükşehir Belediyesi'nin Twitter 
platformunda yaptığı paylaşımların kamuoyunu bilgilendirme ve hizmet odaklı paylaşımlar olduğu düşünüldüğünde belediyenin Twitter'ı kullanım becerisi çok daha hassas ve doğru bir iletişim stratejisi üzerine kurulmalıdır. başlıkların ilk harfleri büyük, diğer harfleri küçük yazılmalı, kalın yazı tipi (bold) kullanılmalıdır. Ara başlıklarda en fazla üç başlık düzeyi kullanılmalıdır.

\subsection{Yöntem ve Bulgular}

Bu araştırmada; Ordu Büyükşehir Belediyesi'nin Twitter platformundan 01.09.2019 - 30.09.2019 tarihleri arasında yaptığı paylaşımlar içerik analizi yöntemiyle incelenmiş ve elde edilen veriler değerlendirilmiştir. Elde edilen veriler doğrultusunda Ordu Büyükşehir Belediyesi'nin kurumsal iletişiminde aktif olarak kullanmış olduğu twitter platformunun, belediyenin kurumsal imajının gelişmesi noktasında daha etkin ve faydalı bir şekilde yönetilmesine ilişkin - kullanılan platformun günümüz teknolojisine entegre olması, platformun teknik özelliklerine uygun paylaşımlar yapılarak paylaşımlarda verilen mesajların daha anlaşılır olması ve Twitter platformunda kuruma ait bilgilerin tamamlanabilmesi gibi - öneriler sunulmuştur.

İçerik analizi yöntemi kullanılarak yapılan bu çalışmada elde edilen bulgular 01.09.2019 - 30.09.2019 tarihleri arasında Ordu Büyükşehir Belediyesinin Twitter platformunda yapılan paylaşımlardan seçilmek sureti ile "Duyuru, Haber, Hizmet, Kutlama, Tanıtım, Ziyaret" kategorilerinde ele alınmıştır. Yapılan paylaşımlar, belirtilen kategoriler çerçevesinde hizmet, eğitim, yapı işleri gibi belirli faaliyet grupları çatısı altında sınıflandırılarak incelenmiştir.

Ayrıca Ordu Büyükşehir Belediyesi'nin Twitter platformu incelenirken; platformun profil sayfasında yer alan hesap isimleri ve hesapların onaylı hesap olup olmaması, başkan bilgileri, kurumlara ait iletişim, adres, web, e-mail ve kurumsal logo görsellerinin yer alıp almamasının yanı sıra platformlardaki takipçi ve gönderi sayıları da dikkate alınmıştır.

\subsection{Amaç}

Bu çalışmanın amacı; Ordu Büyükşehir Belediyesinin kurumsal imaj yönetimine katkı sağlaması amacıyla, Twitter platformunun kullanım biçimini ele alarak bu platformun belediyenin kurumsal imajına sağladığı katkılarını incelemektir. İçerik analizi yapmak üzere Ordu Büyükşehir Belediyesinin Twitter platformundan alınan verilerin yapılan çalışmanın genelinde, belirtilen amaç doğrultusunda kullanılabilecek nitelikte olduğu düşünülmektedir. Yapılan bu çalışmada Ordu Büyükşehir Belediyesinin internet teknolojilerinden yararlanarak kurumsal imajını geliştirmeye yönelik, hedef kitlesi ile karşılıklı iletişimi artırabilmesi gibi durumların kolaylaştırılması amacı ile hazırlanmıştır.

Araştırmamızda; Ordu Büyükşehir Belediyesinin kurumsal imajın gelişmesinde Twitter platformunun, kurumsal imajına nasıl bir katkı sağladığı incelenmektedir. Yapılan araştırma sonucunda ortaya çıkan verilere göre Ordu Büyükşehir Belediyesinin Twitter platformu üzerinden kurumsal imaj oluşturabilmesi amaçlanarak yol gösterici bir çalışma niteliği taşıması hedeflenmiştir.

\subsection{Sinırlılıklar}

$\mathrm{Bu}$ araştırmanın analizi 14.07.2020 tarihinde yapılmış olup Ordu Büyükşehir Belediyesi'nin Twitter platformu incelenmiştir. Araştırma tarihi itibari ile ilgili sosyal medya platformunda yapılan paylaşımlara ait yorum, beğeni, görüntüleme, retweet sayıları, paylaşımların sosyal medya platformlarına eklenmesine ve kaldırılmasına göre değişkenlik gösterebilmektedir. Çalışmaya konu edilen paylaşımların başlıkları yazı karakterleri, imla ve noktalama işaretleri kurallarına bakılmaksızın, metinler olduğu gibi alınarak tırnak işareti kullanılmak suretiyle italik yazı karakterinde çalışmaya eklenmiştir.

$\mathrm{Bu}$ araştırma aşağıda belirtilen sınırlılıklar kapsamında oluşturulmuştur:

- Popüler sosyal medya platformları arasında olan Twitter Platformu incelenmiştir.

- Çalışma Ordu Büyükşehir Belediyesini kapsamaktadır.

- Ordu Büyükşehir Belediyesinin Twitter platformundan 01.09.2019 - 30.09.2019 tarihleri arasında yapmış olduğu paylaşımları incelenmiştir. 


\section{Ordu Büyükşehir Belediyesinin Twitter Kullanımına Genel Bir Bakış}

Çağımızda sosyal medya platformları bireylerin hayatlarında önemli bir yere sahiptir. Sosyal medya platformları arasında yer alan Twitter platformu bireylere mikroblog servisi olarak da hizmet vermektedir. Bireylerin günlük hayatlarında ne yaptığını, ne düşündüğünü ve nerede olduğu gibi bazı bilgilerin, takipçi kitlelerine özetlendiği bir platform olan Twitter (Sayımer, 2008, s. 128), yerel yönetim organlarında da önemli ölçüde kullanılmaktadır. Sosyal medya platformları belediyelerin hedef kitle ile etkileşiminde oldukça önemli bir yere sahiptir. Hedef kitle ile iletişim kurma yönünde alternatif bir yöntem olan sosyal medya; belediyelerin etkinlik ve faaliyetlerini hedef kitlesine aktarabildiği bir mecra haline gelmiştir.

Sosyal medya platformları veri alışverişine ve verilerin hızla yayılmasına olanak sağlamaktadır (Tarhan, 2012, s. 84). Belediyelerin Twitter platformunu tercih etmesi, hedef kitlenin belediyeye sorun ve taleplerini ulaştırma imkânı bularak iletişim kurabildiği bir yapıyı ortaya çıkarmaktadır. (Sayılganoğlu, 2018, s. 390). Araştırmada Ordu Büyükşehir Belediyesi’nin sosyal medya mecralarından olan Twitter platformunun genel görünümü ele alınmıştır. Twitter platformunun; isim bilgisi ve bu hesapların onaylı olup olmaması, belediye başkanı hakkında bilgi, kuruma ait iletişim, web ve telefon bilgilerinin yanı sıra platform üzerinde kurum logosunun yer alıp almadığı ve takipçi sayıları ile gönderi sayıları ele alınmıştır.

Tablo 1 - 01.09.2019 - 30.09.2019 Tarihleri Arasında Ordu Büyükşehir Belediyesi Twitter Platformunun Genel Görünümü

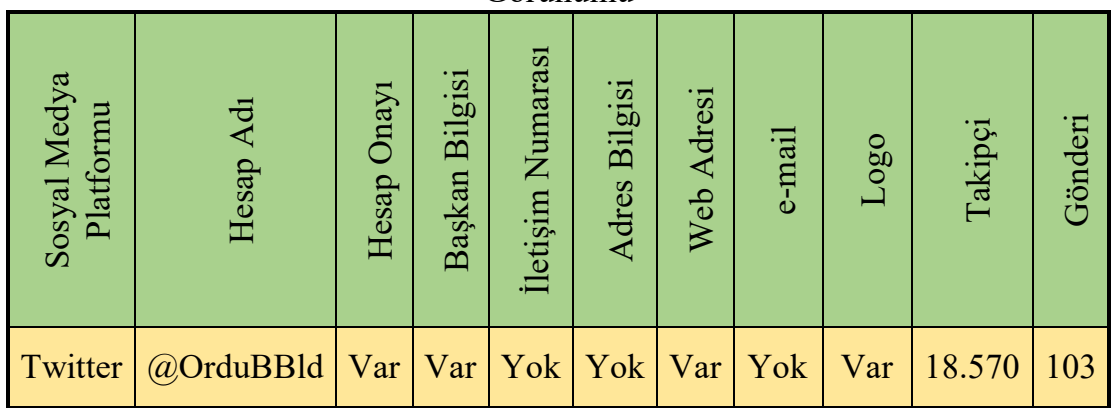

Tablo 1 incelendiğinde; Ordu Büyükşehir Belediyesinin Twitter platformunda belediye başkanına ait bilgilerin yer aldığı̆, iletişim, adres ve e-mail bilgilerinin yer almadığı görülmektedir. Ordu Büyükşehir Belediyesi resmi ve onaylı Twitter platformunda da belirtilen tarihler arasında 103 gönderi paylaşmıştır. Aynı zamanda bahse konu platform 18.570 kişi tarafından takip edildiği görülmüştür.

Yukarıdaki bilgilere göre şunları söylemek mümkündür:

Kente turist olarak gelen bir bireyin karşılaşacağı muhtemel sorunlara karşı belediyeye müracaat etmesi noktasında problem yaşayacağı öngörülebilmektedir. İletişim, adres ve e-mail gibi bilgilerin tamamlanması sosyal medya platformunda kurumsal imajın geliştirilmesi noktasında dikkat edilmesi gereken hususlar içerisinde yer almaktadır.

Belediyenin Twitter platformunun resmi ve onaylı olduğu ve bu platforma belediyenin resmi web sitesi aracılığıla da ulaşılabildiği görülmüştür.

Ordu Büyükşehir Belediyesinin Twitter hesabını onaylı ve resmi olarak kullanıyor olması daha etkin, daha şeffaf, daha faal yönetildiği anlamını taşımaktadır. Aksi yöndeki durumlara sahip olan platformlar ise ilgi görmemektedir. 


\subsection{Ordu Büyükşehir Belediyesinin Twitter Platformundan 01.09.2019 - 30.09.2019 Tarihleri Arasında Yapmış Olduğu Paylaşımların Yükleme Zamanlarına Göre Değerlendirilmesi}

Tablo 2 - Ordu Büyükşehir Belediyesinin 01.09.2019 - 30.09.2019 Tarihleri Arasında Twitter Hesabından Yapmış Olduğu Paylaşımların Yükleme Zamanlarına Göre Dağılımı

\begin{tabular}{|c|c|c|c|c|c|}
\hline Tarih & Paylaşım & Tarih & Paylaşım & Tarih & Paylaşım \\
\hline 01.09 .2019 & 4 & 11.09 .2019 & 5 & 21.09 .2019 & 2 \\
\hline 02.09 .2019 & 4 & 12.09 .2019 & 5 & 22.09 .2019 & 2 \\
\hline 03.09 .2019 & 3 & 13.09 .2019 & 4 & 23.09 .2019 & 3 \\
\hline 04.09 .2019 & 4 & 14.09 .2019 & - & 24.09 .2019 & 2 \\
\hline 05.09 .2019 & 3 & 15.09 .2019 & 2 & 25.09 .2019 & 4 \\
\hline 06.09 .2019 & 5 & 16.09 .2019 & 1 & 26.09 .2019 & 4 \\
\hline 07.09 .2019 & 2 & 17.09 .2019 & 6 & 27.09 .2019 & 6 \\
\hline 08.09 .2019 & 4 & 18.09 .2019 & 6 & 28.09 .2019 & 1 \\
\hline 09.09 .2019 & 3 & 19.09 .2019 & 6 & 29.09 .2019 & 1 \\
\hline 10.09 .2019 & 5 & 20.09 .2019 & 2 & 30.09 .2019 & 4 \\
\hline
\end{tabular}

Yukarıdaki tabloda da gösterildiği gibi Ordu Büyükşehir Belediyesi resmi Twitter platformunda 01.09.2019 30.09.2019 tarihleri arasında 103 paylaşım yapmıştır. Ordu Büyükşehir Belediyesi resmi Twitter platformunda 17 18 - 19 ve 27 Eylül 2019 tarihlerinde yapılan 6'şar paylaşım bahse konu tarihleri arasında en yoğun paylaşım yapılan günler olarak çalışmaya eklenmiştir.

01.09.2019 - 30.09.2019 tarihleri arasında yükleme zamanlarına bakıldığında 16 - 28 ve 29 Eylül 2019 tarihlerinde Ordu Büyükşehir Belediyesi Twitter hesabında sadece 1'er paylaşım yapmış olup 14.09.2019 tarihinde ise herhangi bir paylaşım yapmamıştır.

\subsection{Ordu Büyükşehir Belediyesinin Twitter Platformundan 01.09.2019 - 30.09.2019 Tarihleri Arasında Yapmış Olduğu Paylaşımların Kategorilerine Göre Değerlendirilmesi}

Çalışmanın bu bölümünde Ordu Büyükşehir Belediyesinin Twitter platformu üzerinden 01.09.2019 - 30.09.2019 tarihleri arasında yapmış olduğu paylaşımları kategorilerine göre analiz edilmiştir. Paylaşımlar kategorize edilirken kullanılan başııklara ilişskin açıklamalara aşağıda yer verilmiştir.

Duyuru: Belediyenin yapmayı taahhüt ettiği hizmetlere veya dikkat çekmek istediği konulara ilişkin olarak yaptığı bildirim veya uyarı niteliği taşıyan paylaşımlardır.

Haber: Belediyenin kamuoyunu bilgilendirmek amacı ile yerel ve ulusal alanda paylaştıkları haberlerin bir arada toplandığı başlıktır.

Hizmet: Belediyenin teknik açıdan bakıldığında maddi niteliği bulunmayan ancak belli bir fiyatı olan ve fayda sağlayan yapmayı taahhüt ettiği veya gerçekleştirdiği iktisadi ve sosyal faaliyetlerden oluşan kategoridir.

Kutlama: Belediyenin anma günleri başta olmak üzere etkinlik düzenlediği belirli gün ve haftalar kapsamındaki paylaşımlardan oluşan başlıklardır.

Tanıtım: Belediyenin kentin ön plana çıkmasını istedikleri ve kente özgü özelliklere ilişkin yaptıkları paylaşımlardır.

Ziyaret: Belediyenin kurum içi hizmet birimleri dâhil olmak üzere gerçekleştirdikleri ziyaretleri ve kurum bünyesinde kabul ettikleri ziyaretleri konu edinen paylaşımlardan oluşmaktadır.

Yukarıda sözü edilen kategorilere ilişkin yapılan sınıflandırma incelenmiş olup detayları aşağıdaki bölümlerde aktarılmıştır. 
Ordu Büyükşehir Belediyesi 01.09.2019 - 30.09.2019 tarihleri arasında Twitter hesabından 103 paylaşım yapmıştır. Yapılan paylaşımlar kategorilerine göre incelendiğinde bahse konu tarihler arasında en fazla paylaşımın 44 paylaşım ile 'Hizmet' kategorisinde yapıldığı görülmektedir. 'Hizmet' kategorisinde yapılan paylaşımları ise 30 paylaşımla 'Haber' kategorisi izlemektedir. Adı geçen tarihler içerisinde yapılan en az paylaşım (1 tane) 'Ziyaret' kategorisinde yapılmıştır. 01.09.2019 - 30.09.2019 tarihleri arasında yapılan diğer paylaşımlara ait bilgiler ise aşağıdaki tabloda belirtilmiştir.

Tablo 3 - Ordu Büyükşsehir Belediyesinin 01.09.2019 - 30.09.2019 Tarihleri Arasında Twitter Hesabından Yapmış Olduğu Paylaşımların Kategorilerine Göre Dağılımı

\begin{tabular}{|c|c|c|c|}
\hline Paylaşım İçeriği & Paylaşım Sayısı & Paylaşım İçeriği & Paylaşım Sayıs1 \\
\hline Hizmet & 44 & Haber & 30 \\
\hline Duyuru & 8 & Kutlama & 8 \\
\hline Tanıtım & 6 & Ziyaret & 1 \\
\hline
\end{tabular}

Yukarıdaki tabloda Ordu Büyükşsehir Belediyesinin belirtilmiş olan tarihler arasında kurumsal Twitter platformu üzerinden paylaşmış olduğu tweetler incelenerek; hangi kategoride daha fazla paylaşımda bulunduğu ve bu paylaşımları hangi faaliyet ve çalışmalar üzerine yoğunlaşarak yaptığı irdelenmiştir. En fazla paylaşımı hizmet kategorisinde yaptı̆̆ görülen Ordu Büyükşehir Belediyesinin; adı geçen platformu, misyonuna uygun şekilde çalıştı̆̆ını hedef kitlesine işaret edecek şekilde aktif olarak kullandığı görülmektedir. Bu çıkarımlar özetlendiğinde Ordu Büyükşehir Belediyesinin başta hizmet kategorisi olmak üzere haber, duyuru, kutlama ve tanıtım başlıklı kategorilerde de paylaşımda bulunduğu ancak hizmet ve haber dışındaki kategorilerdeki paylaşımlarını sınırlı tuttuğu görülmektedir. Yapılan bir eylemi duyurma veya bir düşünceyi aktarma mantığı üzerine kurulan Twitter platformunun; Ordu Büyükşehir Belediyesince diğer kurum ve kuruluşlarda olduğu gibi aktif bir şekilde kullanılması, kurumun faaliyet ve çalışmalarının topluma empoze edilmesine zemin hazırlamıştır. Hedef kitlesi ile bu tür paylaşımlar yaparak iletişime geçen Ordu Büyükşehir Belediyesinin, herhangi bir medya ya da yayın organına ihtiyaç duymadan kitlesi ile doğrudan temasta bulunduğu görülmektedir. Ordu Büyükşehir Belediyesi Başkanı Dr. Mehmet Hilmi GÜLER'in resmi ve onaylı Twitter platformundan yapmış olduğu ve yukarıdaki tabloda kategorize edilemeyen 4 paylaşımının, Ordu Büyükşehir Belediyesinin resmi ve onaylı Twitter hesabından retweet aracılığı ile paylaşılması konuya ilişkin en somut örnektir. Tüm bu çıkarımlar ele alındığında Twitter platformu aracılı̆̆ ile yapılan hizmetleri hedef kitlesine duyuran Ordu Büyükşehir Belediyesinin kurumsal imajının gelişmesine katkıda bulunduğu anlaşılmaktadır. Ancak 06.09.2019 tarihli 'Fıskiye çalıştırdık diye, beddua edilmez ki.' şeklindeki tweet ile 10.09.2019 tarihli '\#MilliTakım' tweeti incelendiğinde; bu paylaşımların şekil ve içerik itibariyle kurumsal bir platformda paylaşılabilecek nitelikte, kurumsal bir anlayışa sahip olmadığı ve kurumun imajını zedeleyebileceği düşünülmektedir. 24.09.2019 tarih ve 'DÜNYA BEŞTEN BÜYÜKTÜR' başlıklı tweet; Türkiye Cumhuriyeti Cumhurbaşkanının, BM Genel Kuruluna hitap ederken BM Güvenlik Konseyi’nin 5 daimi üye ülkelerinden bahsettiği konuşmasına ilişkindir. Ancak Ordu Büyükşehir Belediyesinin Twitter platformunda bu konuşmaya ilişkin olarak yer verdiği paylaşımında anlaşılabilir nitelikte herhangi bir bilginin yer almadığı görülmüş olup ilgili paylaşım kategorize edilememiştir. 06.09.2019 tarihli 'Fıskiye çalıştırdık diye, beddua edilmez ki.' şeklindeki tweet Ordu Büyükşehir Belediyesi tarafından yeşil alanlarda fiskiyelerin çalıştırılmasından ötürü duyduğu rahatsızlığı dile getiren vatandaşa cevap niteliğindedir. Ancak paylaşımın şekil ve içerik itibariyle hiçbir kategoride yer bulamamasının yanı sıra, kurumsal imaja sahip bir belediye tarafindan vatandaşa verilebilecek uygun nitelikte bir cevap da olmadığ düşünülmektedir.

\subsection{Ordu Büyükşehir Belediyesinin Twitter Platformundan 01.09.2019 - 30.09.2019 Tarihleri Arasında Yapmış Olduğu Paylaşımların Niteliklerine Göre Değerlendirilmesi}

Çalışma kapsamında Ordu Büyükşehir Belediyesinin Twitter platformunda belirtilen tarihler arasında yapmış olduğu paylaşımların niteliklerine göre ayrımı aşağıdaki bölümlerde gösterilerek detayları aktarılmıştır. Paylaşımlar niteliklerine göre incelenirken bazı anahtar başlıklar kullanılmış olup benzer nitelik taşıyan başlıklar aynı grupta toplanmıştır. Herhangi bir gruba dâhil edilemeyen paylaşımlar ise 'Diğer' başlığı altında değerlendirilmiş olup anahtar başlıklara ilişkin açıklamalara aşağıda yer verilmiştir. 
Başkan Haberleri: Belediye Başkanının kişisel sosyal medya platformlarından alıntı yapılarak ilgili kurumun sosyal medya platformuna aktarılan veya Belediye Başkanının demeçlerine yer verilen ve organik olarak içinde bulunduğu paylaşımlardır.

Denetim: Kurumların bizzat yönetici kadrosu ve kontrol işlevi bulunan çeşitli birimlerince gerçekleştirilen faaliyetleri konu edinen paylaşımlardır.

Ĕgitim: Belediyenin eğitim alanında, eğitim kurumlarına destek amacı ile yaptıkları paylaşımlardır.

Etkinlik: İlgili belediyenin belirli gün ve haftalar kapsamında gerçekleştirdiği anma törenleri ve kentin tanıtımı için yapılan faaliyetlerden oluşan paylaşımlardır.

Halk Sağlığı: Belediyenin toplumsal çevre sağlığının korunmasına ilişkin yaptığı paylaşımlardır.

Kültür Sanat: Kurumun kültürel etkinliklere ve sanata yönelik yaptığı faaliyetlere ait paylaşımlar bu başlık altında toplanmıştır.

Sosyal Yardım: Belediyenin gelir dağılımındaki adaleti ve vatandaşlar arasında eşitliği sağlamak adına ihtiyaç sahiplerine sağladığı imkânları konu edinen paylaşımlardır.

Spor: Bahse konu belediyenin gerek amatör gerek profesyonel alanda yerel, ulusal ve uluslararası boyut taşıyan spor müsabakalarına ilişkin yaptığı paylaşımlardır.

Proje: Belediyenin ekonomik, sosyal, kültürel, bilimsel vb. alanlarda hayata geçirmeyi hedeflediği faaliyetlere ilişkin paylaşımlardır.

Temizlik: Belediyenin asli görevlerinden olan toplumsal hijyeni sağlamaya yönelik yapılan faaliyetlerden oluşan paylaşımlardır.

Ulaşım: Belediyenin kent içerisindeki ulaşımı ve ulaşım ağının düzenlenmesini konu edinen paylaşımlardan oluşan başlıktır.

Yapı İşleri: Belediyenin teknik hizmetlere ilişkin yapmış olduğu paylaşımları konu edinen başlıktır.

Diğer: Yukarıdaki başlıklardan herhangi birine ait olmayan paylaşımlar bahse konu başlıkta toplanmıştır.

Paylaşımların niteliklerine göre dağılımı her iki belediye içinde ayrı ayrı incelenmiş olup detayları çalışmanın ilerleyen bölümlerinde aktarılmıştır.

Ordu Büyükşehir Belediyesinin 01.09.2019 - 30.09.2019 tarihleri arasında Twitter platformunda yapmış olduğu paylaşımlar kategorize edilerek niteliklerine göre değerlendirilmiştir. Ordu Büyükşehir Belediyesi belirtilmiş olan tarihler arasında yapılan 103 paylaşımın kategorilerine göre dağılımı aşağıdaki grafikte gösterilmiştir. Yapılan paylaşımlar 'Duyuru', 'Haber', 'Hizmet', 'Kutlama', 'Tanıtım' ve 'Ziyaret' kategorilerine ayrılmıştır. 
Şekil 1 - Ordu Büyükşehir Belediyesinin 01.09.2019 - 30.09.2019 Tarihleri Arasında Twitter Hesabından Yapılan Paylaşımların Kategorilerine Göre Dağılımı

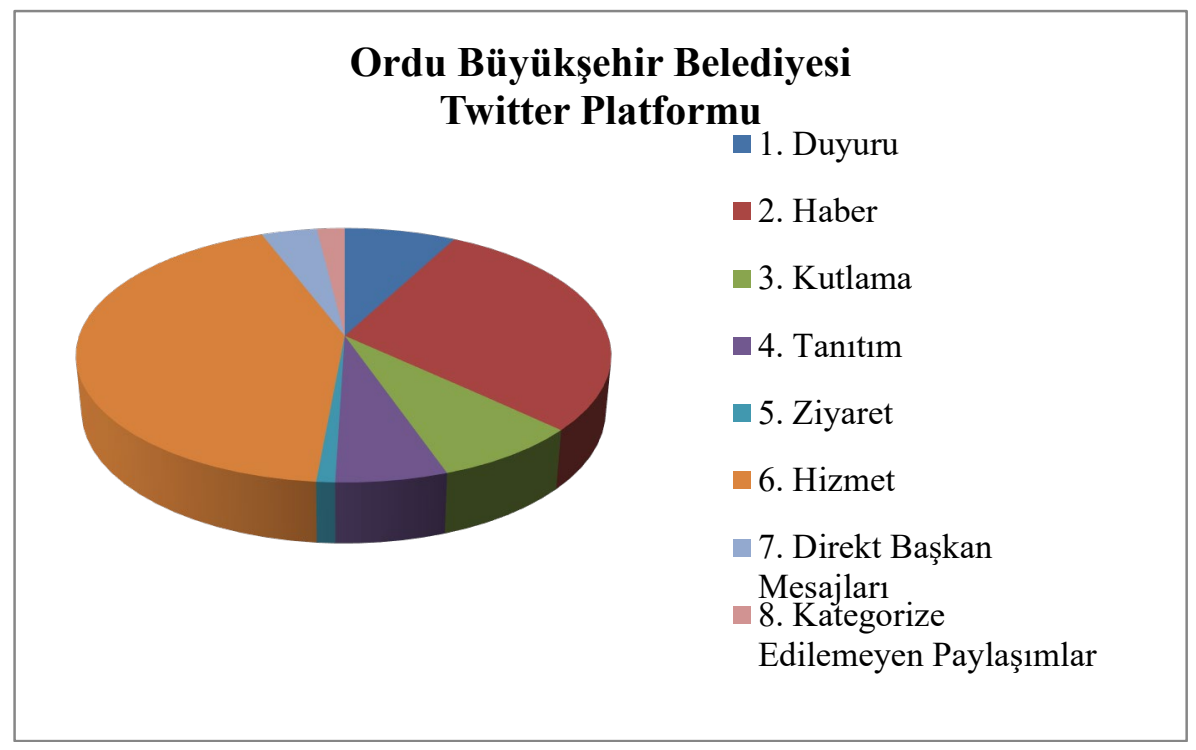

Yapılan paylaşımlar incelendiğinde 'Haber' kategorisinde 30 paylaşım yapıldığı görülmüştür. Bu paylaşımlardan 15'i 'Diğer' niteliğinde ele alınırken, 10 paylaşımın da 'Spor' nitelikli olduğu belirlenmiştir. 'Başkan Haberleri' ve 'Halk Sağlığı' niteliğinde ise 1'er paylaşım yapılırken, 'Etkinlik' niteliğinde ise 2 paylaşım yapılmıştır. 'Duyuru' kategorisinde yapılan 8 paylaşımdan 3 tanesi 'Diğer' niteliğinde, 2'şer tanesi 'Eğitim' ve 'Kültür Sanat' niteliğinde iken 1'i de 'Etkinlik' niteliğindedir. İlgili platformda 'Kutlama' kategorisindeki 8 paylaşımdan 4'ü 'Diğer' niteliğinde ele alınırken 3'ü 'Etkinlik', 1'i de 'Spor' niteliğinde değerlendirilmiştir. Son olarak 'Tanıtım' kategorisinde yapılan 6 paylaşımdan 4'ü 'Diğer', 2'si ise 'Etkinlik’ niteliğinde yapıldığı görülmüştür.

'Hizmet' kategorisinde yapılan 44 paylaşım niteliklerine göre incelendiğinde 29 paylaşımın 'Yapı İşleri' niteliğinde, 3 paylaşımın 'Temizlik' niteliğinde olduğu görülmüştür. 2'şer paylaşımın da 'Ulaşım' ve 'Sosyal Yardım' niteliğinde yapıldığı görülürken 8 paylaşımın ise 'Proje' nitelikli olduğu tespit edilmiştir.

30 Eylül 2019 tarihinde 'Proje' nitelikli yapılan paylaşımın yenilenebilir ve sürdürülebilir enerji kaynaklarına ilişkin olarak güneş enerjisinden elektrik üretilmesi ile ilgili olduğu tespit edilmiştir. Konu edilen paylaşıma eklenen link aracılı̆̆g ile bahsi geçen enerji üretimine ilişkin detaylara ulaşılabildiği görülmüştür. Elektrik enerjisinin daha az maliyetle üretilebilmesi ve bu enerjinin findığın kurutulması ve işlenmesi kapsamında değerlendirilmesini konu edinen projeye 01.10.2019 tarih ve 8419 sayılı Ordu Olay Gazetesinin 3. Sayfasında da yer verildiği tespit edilmiştir. Enerjiyi kaynaklarının kullanımında sürdürülebilir politikayı benimseyen Ordu Büyükşehir Belediyesi planlanan proje kapsamında enerjinin iktisadi kullanımına yönelik bir atılım yapmıştır. Ordu Büyükșehir Belediyesinin planlanan üretim faaliyetiyle, elektrik enerjisinin üretiminde marka değeri olma yolunda adımlar atmaya çalıştığı ve hedef kitle üzerinde marka imajı yaratmaya çalıştı̆̆ düşünülmektedir. Bu paylaşımın, iktisadi bir yaklaşımla enerji üretimine yönelik bir paylaşım olması ve yerel basında yer almasına karşın, Twitter platformunda 38 beğeni aldığı ve hedef kitle üzerinde beklenen etkiyi bırakmadığı düşünülmektedir.

'Ulaşım' niteliğinde yapılan paylaşımlardan “Toplu taşımada 2. Dönem başladı” başlığı taşıyan paylaşım, Ordu'nun toplu taşıma sisteminde yapılan reformla ilgilidir. Yapılan paylaşıma eklenen link aracılığı ile paylaşımda bahsedilen toplu taşıma alanında yapılan köklü değişimin detaylarına ulaşılabildiği görülmüştür. Ulaşım ağının yeniden dizayn edilmesini ve vatandaşların bu konuda duydukları memnuniyeti konu edinen bu habere 06.09.2019 tarih ve 8394 sayılı Ordu Olay Gazetesinin 7. Sayfasında da yer verilmiştir. Bu paylaşım, yenilikçi bir yaklaşımla kentin ulaşım sisteminin revize edilmesine yönelik bir paylaşım olması ve yerel basında yer almasına karşın, Twitter platformunda 33 beğeni almış ve beğeni sayısı yüksek diğer paylaşımlara nazaran geri planda kalmıştır. Kurumsal imaja pozitif yönde direkt etki edebilme potansiyeli taşıyan yukarıda bahsi geçen hizmetlerin, diğer paylaşımlara nazaran geri planda kalmasına; revize edilen ulaşım ağının sadece belli bir kitleyi ilgilendirmesi, yenilenebilir enerji kaynaklarına ilişkin paylaşımın hedef kitle üzerinde gereken farkındalığı yaratamaması veya daha fazla ön plana çıkan paylaşımların varlığı sebep olarak gösterilebilir. 
Tablo 4 - Ordu Büyükşehir Belediyesinin 01.09.2019 - 30.09.2019 Tarihleri Arasında Twitter Hesabından En Az ve En Çok Etkileşime Sahip Paylaşımların Niteliklerine Göre Değerlendirilmesi

\begin{tabular}{|c|c|c|c|c|c|}
\hline Tarih & Kategori & Nitelik & Beğeni & Yorum & Retweet \\
\hline 05.09 .2019 & Haber & Diğer & $3,7 \mathrm{~B}$ & 36 & $1,2 \mathrm{~B}$ \\
\hline 10.09 .2019 & Haber & Diğer & 11 & 0 & 1 \\
\hline
\end{tabular}

Ordu Büyükşehir Belediyesinin Twitter platformunda 05.09.2019 tarihinde "Eli öpülesi koca yürekli analar bitirecek PKK'yı." iletisiyle yaptığı paylaşımın çalışmaya esas tarih aralığında en fazla beğeni alan, en fazla yorum yapılan ve en fazla retweet yapılan paylaşım olduğu tespit edilmiştir. Bu paylaşım; silahlı terör örgütüne cebren dâhil edilmek amacıyla kaçırılan gençlerin, aileleri tarafindan başlatılan ve annelerinin öncülük ettiği ülke genelinde büyük yank1 uyandıran ve hala devam etmekte olan Diyarbakır Annelerinin oturma eylemini konu edinmektedir. 3,7B beğeni alan ve toplumun tüm kesimlerini ilgilendiren ve toplumsal dayanışmayı destekleyen bu paylaşımın Ordu Büyükşehir Belediyesi tarafından resmi ve onaylı Twitter platformundan paylaşılması, ilgili kurumun toplumsal sorunlara duyarlı olduğunu ve takipçi kitlesi üzerinde farkındalık yaratmaya çalıştığını göstermektedir. Bu açıdan değerlendirildiğinde merkezi yönetimin alt birimi olan bir kurumun bu eylemi desteklemesinin kurumun misyonu ve vizyonu düşünüldüğ̈̈nde kurumsal imajın gelişmesi bakımından etkin bir role sahip olduğu sonucu çıkarılmaktadır. Ayrıca yapılan araştırma kapsamında bu paylaşımın sadece Twitter platformu üzerinden yapıldı̆̆ 1 diğer sosyal medya platformlarında bu konuya yer verilmediği tespit edilmiştir. Bu açıdan bakıldığında Ordu Büyükşehir Belediyesi diğer platformlarında da bahse konu paylaşıma yer vererek bu paylaşımı daha geniş kitlelerle buluşturabilme şansını kullanamamıştır. Bütün sosyal medya platformlarında hesabı olmayan, bu platformlardan sadece birini ya da bir kaçını kullanmayı tercih eden bireyler olduğu düşünüldüğünde tüm sosyal medya platformlarının birbirine entegre şekilde kullanılmasının sosyal medya yönetiminin daha profesyonel yapılmasını sağlayacaktır. İlgili kurumun Facebook platformundaki takipçi sayısının Twitter platformundan daha fazla olduğunun göz önünde bulundurulması, platformların entegre kullanılmasının sağlayacağı faydayı açıkça ortaya koymaktadır.

11.09.2019 tarihinde “Büyükşehir Belediye Başkanları Toplantısı” başlığı ile Recep Tayyip ERDOĞAN'ın resmi ve onaylı Twitter hesabından yapmış olduğu paylaşımı, Ordu Büyükşehir Belediyesinin retweet yaparak kendi platformunda paylaştığı görülmüştür. Bu paylaşım 15,B (ortalama on beş bin) beğeni aldığı halde platformun özelliği gereği paylaşımın beğeni sayıları, paylaşımı yapan kişinin platformuna ait veriler olduğundan dolayı çalışmaya dâhil edilmemiştir. Ayrıca belirtilmiş olan tarihler arasında yapılan paylaşımlar incelendiğinde 1'er retweet alan çok sayıda paylaşım olduğundan ilgili paylaşımlar yukarıdaki tabloda yer almamıştır. Ordu Büyükşehir Belediyesinin, Belediye Meclisinin Eylül Ayı Olağan Toplantısının yapıldı̆̆ına ilişkin 10.09.2019 tarihinde 'Haber' kategorisinde yaptığı paylaşımın, 11 beğeni ile en az beğeniyi alan paylaşım olduğu gözlenmiştir. Belediyenin karar organı olan meclisin aylık olağan toplantısının yapılması, ilgili kurumun işbaşında olduğunu ve asli faaliyetlerini yerine getirdiğine işaret ettiğinden kurumsal imaj açısından önemlidir. Kurumsal imajın gelişmesi bakımından önemli olduğu düşünülen bu paylaşımın en az beğeniyi alan paylaşım olması, bu gönderi ile kullanıcı kitlesine verilmek istenen mesajın işlevini yerine getiremediğini ve paylaşımdan beklenilen verimin alınamadığını göstermektedir. Bahse konu paylaşıma, meclis toplantısı sonucunda alınan kararlara erişim sağlayacak bir link eklenmiş olsaydı, bu paylaşımın kullanıcı kitlesi tarafından daha yoğun ilgi göreceği ve kurumsal imajın gelişimi açısından daha etkili olabileceği düşünülmektedir.

\section{SONUÇ:}

Kurumsal imaj yönetimi açısından sosyal medya platformlarının kullanılması, teknolojik imkânların gelişmesiyle ve yaygınlaşmasıyla ivme kazanmıştır. Günümüzde bu tip iletişim araçları; etkili ve yaygın bir şekilde etkileşim tabanlı iletişim sağlamaktadır. Yerel yönetimlerde kurumsal imaj faaliyetleri kapsamında; sosyal medya platformları tercih edilmektedir. Geri bildirim hızı, verilere anında ulaşabilme imkânı vb. bir takım kolaylıklar kurumsal imajın oluşumuna katkı sağlamaktadır.

Kurum ve kuruluşlar; internet platformları aracıllğıyla ulaştığı hedef kitlelerinden, almış olduğu geri bildirimler sonucunda, sosyal medya platformlarını kullanarak hizmet kalitesine ivme kazandırmıştır. Bu platformlarda yapılan paylaşımların; amacına uygun, platformun özelliklerine göre ve doğru bir düzlemde yapılması gerekmektedir. Yoğun olarak kullanılan ve her geçen gün gelişen internet teknolojileri yerel yönetimlerin de vazgeçilmez bir unsuru haline gelmiştir. Belediyeler son yıllarda yapmış olduğu faaliyetleri hedef kitlesine iletmek için internet dünyasının imkânlarından faydalanmayı tercih etmektedir. Belediyeler faaliyetlerini; sosyal medya platformları başta olmak üzere 
kurumsal web siteleri aracılığıyla da hedef kitlesine ulaştırmalıdır. Gerek bilgisayar ortamında gerek mobil cihazlar ortamında kullanım kolaylı̆̆ sağlayan bu platformlar birçok kurum gibi yerel yönetimlerinde ilgisini çekmektedir. Belediye sınırları içerisinde yaşayan halkın; istek, talep, şikâyet ve önerilerini değerlendirebildikleri bu platformlar demokratik yaşamında olmazsa olmazıdır.

Yapılan çalışmanın sonucunda 01.09.2019 - 30.09.2020 tarihleri arasında Ordu Büyükşehir Belediyesinin Twitter platformunu aktif bir biçimde kullandığ görülmüştür. Ordu Büyükşehir Belediyesinin Twitter platformu üzerinden yapmış olduğu paylaşımları incelenerek hedef kitlesiyle karşılıklı bir iletişim biçimi sağladığı görülmüştür. Belirtilen tarihler arasında yapılan paylaşımlar kamuoyunu bilgilendirme ve hizmet odaklı yaklaşım barındıran paylaşımlardır.

Örneğin Ordu Büyükşehir Belediyesinin 05.09.2019 tarihinde yapmış olduğu Diyarbakır Annelerini konu edinen paylaşımı Twitter platformunun en fazla beğeni alan paylaşımı olurken ulusal basında da geniş yer edinmiştir. Bahse konu haberin ulusal basında yer bulması ve Türkiye gündeminde hala sıcaklığını koruyor olması haberin önemini vurgulamaktadır. Sosyal medya platformu üzerinden yayınlanan haber çok daha geniş kitlelere ulaşarak, haberin kitleler üzerinde oluşturacağı etkinin gücünü artırmıştır. Ordu Büyükşsehir Belediyesinin toplumsal açıdan hassasiyet taşıyan bir eylem karşısında göstermiş olduğu destek verici yaklaşımı, kurumsal kimlik ve kurumsal imaj açısından sergilediği duruşu göstermektedir. Bu bakımdan sosyal medyanın; daha geniş kitleler üzerinde göstereceği etkinin, kurumsal imajın gelişimi açısından rolü daha anlaşılır bir biçimde ortaya çıkmaktadır.

Toplumun bireyleri, örf ve adetleri gibi teknoloji de hızlı bir değişimin içindedir. Hızla değişen bu sistem içerisinde, kurum ve kuruluşların da bu değişimden payını alması kaçınılmazdır. Kitlelerce takip edilen teknolojik gelişmeler, belediyelerin de kurumsal hizmet anlayışını etkilemektedir. Belediyelerin; hedef kitlesine karşı hizmetlerini ve hedeflerini amacına uygun ve doğru bir düzlemde aktarabilmek ve her geçen gün iletişime geçilen kitleyi artırabilmek adına çalışmalarını sürdürdüğü görülmektedir. Belediyelerde bu sürecin itina ile yönetilmesi kurumsal imajın gelişmesine katkı sağlayacağı düşünülmektedir. Kurumsal imaj yönetimini ön planda tutma niyetinde olan Ordu Büyükşehir Belediyesinin aşağıdaki hususları önemsemesi gerekmektedir.

- Kurumsal imajın sosyal medyadaki rolü açısından, bu tür platformların profesyonel bir anlayışla yönetilmesi önemli bir gerekliliktir. Kurumsal imajın gelişmesi noktasında yapılan paylaşımların bir standardizasyon çerçevesinde yapılması kurumsal imaj açısından önemli bir detaydır.

- Bireyler gibi kurum ve kuruluşlarda geleneksel medya organları yerine sosyal medya platformlarını tercih etmektedir. $\mathrm{Bu}$ nedenle; internet kavramının içinde yer alan sosyal medya platformları her yönü ile çağın gerekliliklerine göre yönetilmesi gerekmektedir.

- Twitter platformunda video formatı ile eklenen içeriklerin ses ve görüntü kalitesine özen gösterilmeli, montaj çalışmalarının paylaşımlarda verilmek istenen mesaja uygun ve anlam bütünlüğü taşıyacak şekilde yapılması gerektiği düşünülmektedir.

- Belediyenin Twitter platformunda bulunan takipçi sayılarının güncelliği korunmalı ve daha çok kitleye ulaşabilmek adına takipçi sayılarının artmasına yönelik çalışmalar yapılmalıdır.

- Sosyal medya platformlarının kullanıcı profilleri göz önünde bulundurulduğunda her platformun kendine özgü kullanıcı kitlesi bulunmaktadır. Ordu Büyükşehir Belediyesinin Twitter platformu başta olmak üzere belediyenin kullanmış olduğu diğer sosyal medya platformlarında yapılan paylaşımların birbirine entegre olması kurum açısından faydalı olacaktır.

- Ordu Büyükşehir Belediyesince aktif olarak kullanılan Twitter platformunda kuruma ait bilgilerin eksiksiz olarak yer alması kurumsal imajlarına katkı sağlayacaktır.

- Kurumda çalışan personelin Ordu Büyükşehir Belediyesine ait sosyal medya platformlarını takip ediyor olması kurumsal imajın oluş̧urulması noktasında önemli bir adımdır. Kurum personelinin, kurumun hedef kitlesine karşı bir yüzü olduğu düşünüldüğünde bu durum güçlü bir iç imaj oluşturulması açısından oldukça önemlidir. Hiyerarşik düzenin bir parçası olan kurum içi personelin bu etkileşim halkasına dâhil edilmesi kurumsal imaj çalışmaları açısından önemlidir.

- Çalışma kapsamında; Ordu Büyükşehir Belediyesinin Twitter platformunda yapmış olduğu paylaşımlar incelenirken, web ortamında ilgili belediyenin adını taşıyan bazı Twitter platformlara rastlanmıştır. İncelenen bu platformların 
gerçek olmadığı ve ilgili kurum tarafindan yönetilmediği tespit edilmiştir. Ordu Büyükşehir Belediyesinin Twitter platformunu resmi ve onaylı olarak kullanıyor olması kurumsal imajın gelişmesine katkı sağladığı düşünülmektedir.

- Radyo, televizyon ve basılı yayınları içerisine alan geleneksel medya organları yaşanan günlük olaylardan haberdar olmamızı sağlamaktadır. Teknolojinin hız kazanmasıyla birlikte kullanıcılar sosyal medya platformlarında canlı yayın yapabilme imkânı elde etmiştir. Vatandaş ile iç içe yönetim felsefesini sergileyen belediyeler bazı faaliyetlerini hedef kitlesine şeffaflık ilkesiyle iletmesi gerektiği düşünülmektedir. Çalışmaya konu edinen Twitter platformunun canlı yayın yapabilme özelliği sosyal medyayı geleneksel medyadan daha ileriye taşımaktadır. Ordu Büyükşehir Belediyesi, Twitter platformu üzerinden yapmış olduğu çalışmaları (ihale, belediye meclis toplantısı gibi) şeffaf bir şekilde hedef kitlesine sosyal medya üzerinden aktarması sonucunda belediyenin kurumsal imajının gelişmesine katkı sağlayacağı düşünülmektedir.

\section{Etik Standart ile Uyumluluk}

Çıkar Çatışması : Yazarlar, kendi aralarında ve diğer üçüncü kişilerle herhangi bir çıkar çatışmasının olmadığını beyan eder.

Etik Kurul İzni : Bu çalışma için etik kurul iznine gerek yoktur.

Finansal Destek : Yok

\section{KAYNAKÇA:}

Aydın, M. P., Belediyelerde Halkla İlişkiler Aracı Olarak Sosyal Medya Kullanımı: Büyükşehir Belediyelerinin Twitter Hesapları Üzerine Bir İnceleme, (Yayımlanmamış Yüksek Lisans Tezi), Marmara Üniversitesi Sosyal Bilimler Enstitüsü, İstanbul, 2018.

Canöz, N., Hizmet Sektöründe Kurumsal İmaj Algısı: Türk Hava Yolları Örneği, (Yayımlanmamış Yüksek Lisans Tezi), Selçuk Üniversitesi Sosyal Bilimler Enstitüsü, Konya, 2015.

Chun, S. A., Shulman, S., Sandoval, R. ve Hovy, E., (2010). "Government 2.0: Making Connections Between Citizens, Data and Government", Information Polity, 15, 1-9.

Çavuş, S., Yeni İletişim Teknolojilerinde İnternet Ve Halkla İlişskilerdeki Yerinin İncelenmesi: Talas Belediyesi Örneği, (Yayımlanmamış Yüksek Lisans Tezi), Erciyes Üniversitesi Sosyal Bilimler Enstitüsü, Kayseri, 2011.

Demirkol, N., Belediyelerde Kurumsal İmaj Algısı Kırıkkale Belediyesi’nin Dıı̧ Hedef Kitleler Gözündeki İmajı, (Yayımlanmamış Yüksek Lisans Tezi), Selçuk Üniversitesi Sosyal Bilimler Enstitüsü, Konya, 2017.

Doğan, T., Yeni Reklam Araçları Ve Kurum İmajı Oluşturma Sürecine Katkıları, (Yayımlanmamış Yüksek Lisans Tezi), Selçuk Üniversitesi Sosyal Bilimler Enstitüsü, Konya, 2006.

Duvan, Y., Karadeniz Bölgesindeki Belediyelerin Kurumsal İletişiminde Sosyal Medya, (Yayımlanmamış Yüksek Lisans Tezi), Ordu Üniversitesi Sosyal Bilimler Enstitüsü, Ordu, 2019.

Kaygısız, Ü., Sarı, S., Belediyelerin Sosyal Medya Kullanımı: Burdur Belediyesi ve Burdur İlçe Belediyeleri Üzerine Bir Araştırma, International Journal of Social Sciences and Education Research,1 (2), 2015, 309-317. Doi: $10.24289 /$ ijsser. 106417

Ordu Olay Gazetesi, Yeni Stadın Eksikleri Giderilecek, S.8394, s.8, 06.09.2019.

Ordu Olay Gazetesi, Enerjiyi Güneşten Alacağız!, S.8419, s.3, 01.10.2019.

Öztel, H., Kamu Kuruluşlarında Sosyal Medya Kullanımının Kurumsal İmaj Açısından Rolü: Anadolu Üniversitesi Örneği, (Yayımlanmamış Yüksek Lisans Tezi), Anadolu Üniversitesi Sosyal Bilimler Enstitüsü, Erzurum, 2018.

Sayımer, İ., (2008). Sanal Ortamda Halkla İlişkiler, İstanbul: Beta Yayınları. 
Tarhan, A. (2012). Büyükşehir Belediyelerinin Sosyal Medya Uygulamalarına Halkla İlişkiler Modellerinden Bakmak. İletişim Kuram ve Araştırma Dergisi, 35, 79-101. http://www.acarindex.com/dosyalar/makale/acarindex1423903284.pdf

Tokatlı, M., Sosyal Medya'da İtibar Yönetimi: Üniversiteler Üzerine Bir Araştırma, (Yayımlanmamış Yüksek Lisans Tezi), Ege Üniversitesi Sosyal Bilimler Enstitüsü, İzmir, 2015.

Yavuz, C., Duvan, Y., Doğu Laradeniz Üniversitelerinin Kurumsal İletişimde Sosyal Medya Kullanım Alışkınlığı, Gümüşhane Üniversitesi İletişim Fakültesi Elektronik Dergisi, C. 6, S.2, 2018, s.1329 - 1350. 